aversive stimulus (e.g., electric shock) and withholding a rewarding stimulus (e.g., nonreward of a leverpress during the $S$ trial) are both punishment procedures. Since amphetamine drugs reduce shock-punished responding, one might predict that amphetamine drugs also would reduce nonrewarded responding. Thus, one explanation of how methamphetamine affects SDR acquisition is that is reduces the probability of nonrewarded responses ( $\mathrm{S}$ - responses), thus reducing the number of errors to criterion.

Regarding duration of the drug effect in SDR, any conclusion is tentative. With $0.5 \mathrm{mg} / \mathrm{kg}$ of methamphetamine, the drug group performed better than its control group for several reversals after the drug injection (i.e., long-term effect). Yet, in Experiment II, with reversals spaced by $48 \mathrm{~h}$, the drug effect did not persist beyond $R_{4}$ (i.e., short-term). Since a "long-term" effect was present with 24-h spacing of reversals, but not with 48-h spacing of reversals, the results suggest that the drug had a residual effect on the performance of the animal which dissipated with time, and when reversals were spaced by $48 \mathrm{~h}$, the drug effect had vanished by $R_{5}$.

\section{REFERENCES}

Bauer, R. H., \& Duncan, N. C. Twenty-four proactive facilitation of avoidance and discrimination learning in rats by d-amphetamine. Journal of Comparative \& Physiological Psychology, 1971, 77, 521-527.

Cole, S. O. Experimental effects of amphetamine. A review. Psychological Bulletin, 1967, 68, 81-90.

Geller, L., \& Seifter, L. The effects of meprobamate, barbiturates, d-amphetamine, and promazine on experimentally induced conflict in the rat. Psychopharmacologia, 1960, 1, 482-492.

Grossman, S. P.. \& Sclafani, A. Sympathomimetic amines. In E. Furchtgott (Ed.), Pharmacological and biophysical agents ard behavior. New York: Academic Press, 1971. Pp. 269-344.

Kelleher, R. T., \& Morse, W. H. Determinants of the specificity of behavioral effects of drugs. Ergebnisse der Physiologie Biologischen Chemie und Experimentalen Pharmakologie. Biologischen $1968,60,1-56$.

Kulig, B. M., \& Calhoun, W. H. Methamphetamine enhancement of successive discrimination reversal learning. Psychopharmacologia, 1972, 27, 233-240.

(Received for publication October 23, 1973.)

\title{
Effects of positive and negative requests on compliance following transgression*
}

\section{DAVID L. McMILLEN $†$, JERRY A. JACKSON and JAMES B. AUSTIN \\ Mississippi State University, Mississippi State, Miss. 39762}

Fifty Ss were assigned randomly to four cells of a 2 by 2 factorial design. Half the $S$ s were induced to transgress by cheating on a multiple-choice psychology test, while half the Ss did not transgress. Following the transgression manipulation, 28 of the Ss from each of the above conditions were asked to circulate a petition

*This research was partially supported by a National Science Foundation Institutional Allowance to Mississippi State University. This paper is sponsored by Jeff $S$. Topping, who takes editorial responsibility for its contents.

+Reprints may be obtained from David L. McMillen, Drawer PF, Mississippi State, Miss. 39762. on an issue which was socially desirable while 22 Ss from each condition were requested to circulate a petition on an issue which was not socially desirable. The findings were: (a) the greatest degree of compliance was found in the transgress-socially desirable request group; (b) Ss who had transgressed would not comply to a negative request more than Ss who had not transgressed. Results indicate that greater compliance occurs following transgression if compliance functions to raise self-esteem.

Numerous studies have indicated that transgression leads to an increase in compliant behavior. Transgression has been made operational in a variety of ways, including destroying a machine (Wallace \& Sadalla, 
1966). upsetting the order of a graduate student's index cards (Freedman. Wallington, \& Bless. 1967). costing another person green stamps (Berscheid \& Walster. 1967). lying (Freedman, Wallington. \& Bless, 1967), and administration of electric shocks (Carlsmith \& Gross, 1969). and the results have been essentially the same-transgression tends to increase compliance.

Several studies (e.g., Carlsmith \& Gross, 1969; McMillen, 1971: McMillen \& Austin, 1971) have indicated that self-esteem is an important factor in the transgression-compliance relationship. It is probable that the act of transgression is inconsistent with the individual's self-concept. The compliance request gives the individual an opportunity to restore self-esteem, thus reducing the inconsistency. This interpretation is derived from a revision of dissonance theory by Aronson (1969). According to Aronson, cognitive dissonance is aroused when a cognition about a behavior is inconsistent with a cognition about the self. In most transgression-compliance studies $S$ is probably faced with this type of inconsistency. $\mathrm{S}$ has a negative cognition concerning his behavior (e.g.. "I damaged a machine.". "I lied.", "I cheated.") and a positive cognition of himself (e.g., "I am a good, honest person."). This situation should arouse dissonance.

The self-esteem interpretation implies that persons will comply following transgression only when the act of compliance can function to restore self-esteem. If this is true. a factor such as the social desirability of the request may be important in determining if compliance occurs.

Previewed briefly, the present experiment consisted of a 2 by 2 factorial design in which Ss were either given or not given information conducive to transgressing (cheating on a test) and subsequently asked to comply with a request of positive or negative social desirability. The greatest degree of compliance was predicted in the transgression-positive request group. since the nature of the request should afford these Ss an opportunity to restore self-esteem. Also, no significant differences were predicted between the transgression and no-transgression groups in the negative request condition since compliance to a negative request should not restore self-esteem.

\section{METHOD}

Subjects

The Ss were 50 female undergraduate students enrolled in a general psychology course at Mississippi State Lniversity. ${ }^{1} \mathrm{Ss}$ volunteered to participate in the experiment in order to partially fulfill a course requirement. No Ss were in classes with either of the Es or the confederate.

\section{Procedure}

Ss were run individually. As each $\mathrm{S}$ arrived for the experiment. she was met by $E_{1}$, seated in a waiting room. and told that the previous $S$ had not yet completed the experiment. $E_{1}$ then left $S$ alone to wait. One minute later. a confederate posing as the previous $S$ entered the waiting room on the pretext that she had left her bcoks there. The confederate engaged $S$ in a brief informal discussion. During the course of this discussion, the confederate provided half the Ss with the following information: "I was just in an experiment where I had to take a psy.chology test. The girl told me if I made a good score, it would help my psychology grade: but I didn't do well. She went over the test with me and most of the correct answers were B."

The other half of the Ss were also engaged in a conversation. but the confederate did not discuss the experiment. In both conditions, the confederate left $\mathrm{S}$ alone to wait for $\mathrm{E}$ after the condition had been introduced.

One minute later, $E_{2}$ (who was condition-blind) entered the waiting room and introduced herself as the $E$. She asked the $S$ if she had heard anything about the experiment or had been in it before (all Ss answered "no"). She then took S io the testing room, seated S, and began to explain the purpose of the experiment. The following instructions were given to each $\mathbf{S}$ : "The psychology department is participating in a self-study program being carried on by the university. The purpose of the program is to assess the strengths and weaknesses of existing courses and to determine if new courses are needed. In this experiment we are trying to find out how much students know about theories of personality and abnormal psychology before they study it in their class. By doing this we will be better able to plan future course work. You will be given a standardized multiple choice test to determine how much you already know. It is important that we get a true indication of your knowledge of psychology since the results of the tests will help us determine how the course will be taught in the future. Since this is a test of your knowledge of psychology you will receive extra credit toward your course grade if you do well. If, however, you do not not do well, the test will not be counted against you, since you are not held responsible for material you have not yet covered in class." $\mathrm{S}$ was then given the test, and $\mathrm{E}_{2}$ left her alone to complete the work.

The test given to all Ss was a multiple-choice test containing 50 questions concerning theories of personality and abnormal psychology. Four possible answers were listed with each question. and were designated as "A, B, C, and D." The correct answers were randomly distributed according to letter designations, but only 10 of the correct answers were "B."

When $S$ finished the test, $E_{2}$ collected it and presented $S$ with a receipt for experimental credit. At this point, $E_{2}$ randomly administered either the positive request $(P R)$ or negative request (NR) for compliance.

In order to determine a valid positive and negative request. a survey questionnaire had been administered to undergraduate students enrolled in a general psychology course at Mississippi State University. The questionnaire was administered twice-2 weeks before the experiment began, and 2 weeks after the experiment was terminated. The issue which received the most support and the highest rank of importance was a statement concerning a new coliseum at the university. Of the females, 89? either strongly agreed or agreed that the university needed a new coliseum and 76\% ranked the coliseum issue as an important issue. After the experiment was terminated, 24 females were surveyed. None of these students had participated in the experiment or been surveyed. Of these 24 females, $89 \%$ either strongly agreed or agreed that the university needed a new coliseum, and 83 ranked the coliseum issue as an important issue.

For each of the $28 \mathrm{Ss}$ in the PR condition, $\mathrm{E}_{2}$ made the request in the following manner: "I am a member of a committee trying to persuade the state legislature to approve funds for a new coliseum here at the university. In order to influence the legislature we need as many signatures as possible on petitions. Of course you are under no obligation, but it would certainly be helpful if you could circulate this petition (showing $\mathrm{S}$ a petition) and try to get signatures. Will you help?" If $\mathrm{S}$ gave an affirmative response. $F$. asked $S$ how much time she would spend in 1 week circulating the petition. For each of the 22 Ss in 
the NR condition. $E_{2}$ administered the compliance measure exactly as described above, except that $E_{2}$ identified herself as a member of a committee attempting to persuade the legislature to approve funds designated for better educational services as opposed to funds designated for a coliseum. Also, a different petition was shown to $S$.

Following completion of the questionnaire, each $S$ was throughly debriefed and requested not to discuss the experiment with others.

\section{RESULTS AND DISCUSSION}

An analysis of variance was performed on the data for the number of " $B$ " responses. The information (I) group means were significantly higher than the no-information (NI) group means $(F=17.26, \mathrm{df}=1 / 46, \mathrm{p}<.01)$. The NI group means for " $B$ " responses were about equal to the chance level (12.5). It may be concluded that Ss in the I groups used the confederate's information and cheated on the test.

The postexperimental questionnaire provided some interesting data regarding cheating. Fourteen Ss in the I groups admitted cheating, while 11 Ss indicated that they did not make use of the information. Of these 11,4 had scores below chance and 7 had scores above chance. The mean number of " $B$ " answers for these 7 Ss was 16.8 , which is about equal to the mean for all I Ss. Apparently, only 4 of the 25 Ss did not use the information received.

The compliance data are shown in Table 1. Median tests were used to test for differences in amount of compliance because the open-ended nature of this response measure (i.e., the number of hours Ss agreed to circulate the petition) led to a highly skewed distribution of values. Comparisons between PR and NR Ss showed that significantly more compliance occurred among the PR groups $\left(\chi^{2}=9.82, \mathrm{df}=1, \mathrm{p}<.01\right)$. In addition, Ss in the I-PR group were signficantly higher than Ss in the NI-PR group with respect to the degree of compliance $\left(\chi^{2}=7.0, \mathrm{df}=1, \mathrm{p}<.01\right)$. Analysis of the data for the two NR groups did not yield a significant difference $\left(\chi^{2}=3.0, \mathrm{df}=1, \mathrm{p}>.05\right)$.

The data support the prediction that compliance is greater when the request has positive social desirability. Actually, compliance was quite minimal when the negative request followed the transgression. Theoretically, the positive request gives the individual an opportunity to bolster self-esteem, which was lowered as a result of transgression. Compliance to a negative request could damage the self-esteem even more; at best, it would only maintain the status quo.

Table 1

Measures of Compliance for Each Group

\begin{tabular}{lll}
\hline & \multicolumn{1}{c}{ Information } & No Information \\
\hline Positive & Median $=3.5 \mathrm{~h}$ & Median $=1.75 \mathrm{~h}$ \\
Request & Mean $=3.7 \mathrm{~h}$ & Mean $=2.0 \mathrm{~h}$ \\
& $\mathrm{~N}=14$ & $\mathrm{~N}=14$ \\
Negative & Median $=.5 \mathrm{~h}$ & Median $=0 \mathrm{~h}$ \\
Request & Mean $=.7 \mathrm{~h}$ & Mean $=.4 \mathrm{~h}$ \\
& $\mathrm{~N}=11$ & $\mathrm{~N}=11$ \\
\hline
\end{tabular}

The postexperimental questionnaire yielded some informative data regarding the method of dissonance reduction in this experiment. Of the Ss in the NI group, $44 \%$ indicated that if they had received information they would have used it in order to gain a higher test score. Also, $80 \%$ of the NI Ss indicated that they would have had feelings of transgression if they had cheated. In contrast, only three Ss (12\%) in the I groups indicated that feelings of transgression were present. If an individual commits an act which he regards as wrong (e.g., cheating), his cognition of this act is probably dissonant with his positive cognitions of himself. The individual may strive to reduce his dissonance in a number of ways. As previously noted, one way in which dissonance could be reduced would be for the individual to change his attitude concerning the behavior which aroused the dissonance. Mills (1958) has found empirical evidence supporting this prediction regarding cheating behavior. It appears likely that in the present experiment Ss tended to reduce dissonance by complying, convincing themselves they had not transgressed, or both.

This experiment seems to indicate, as did prior experiments by Carlsmith and Gross (1969) and McMillen (1971) that Ss in a transgression-compliance study are primarily concerned with what the act of transgression does to them. The inconvenience or injury of the victim seems secondary. However, it should be noted that the types of transgression manipulations employed have not been extremely powerful. Presumably, acts of transgression which caused the victim substantial injury or loss would lead to a greater desire by the transgressor to help the victim.

\section{REFERENCES}

Aronson, E. The theory of cognitive dissonance: A current perspective. In L. Berkowitz (Ed.), Advances in experimental social psychology. Vol. 4. New York: Academic Press, 1969. Pp. 1-34.

Berscheid, E., \& Walster, E. When does a harm-doer compensate a victim? Journal of Personality \& Social Psychology, 1967, 6, a victim?

Carlsmith, J. M., \& Gross, A. E. Some effects of guilt on compliance. Journal of Personality \& Social Psychology, $1969,11,232-239$.

Freedman, J. L., Wallington, S. A., \& Bless, E. Compliance without pressure: The effect of guilt. Journal of Personality \& Social Psychology, 1967, 7, 117-124.

McMillen, D. L. Transgression, self-image and compliant behavior. Journal of Personality \& Social Psychology, 1971, 20, 176-179.

McMillen, D. L., \& Austin, J. B. Effect of positive feedback on compliance following transgression. Psychonomic Science, $1971,24,59-61$.

Mills, $\mathbf{J}$. Changes in moral attitudes following temptation. Journal of Personality, 1958, 26, 517-531.

Wallace, J., \& Sadalla, E. Behavioral consequences of transgression: I. The effects of social recognition. Journal of Experimental Research in Personality, 1966, 1, 187-194.

\section{NOTE}

1. Originally, $15 \mathrm{Ss}$ were planned for each cell of the design; however, the Mississippi Legislature appropriated funds for a new coliseum a few days before the scheduled termination of the experiment. This necessitated concluding the experiment with $14 \mathrm{Ss}$ in the two PR cells and $11 \mathrm{Ss}$ in the two NR cells.

(Received for publication October 23, 1973.) 